\section{Ellipsis Unsur Kalimat Dalam Percakapan Psikoterapi}

\author{
Fina Muhimah \\ Graduate Program of Linguistics, \\ Universitas Gadjah Mada \\ fina.muhimah23@gmail.com
}

\begin{abstract}
ABSTRAK
Ellipsis atau pelesapan adalah hilangnya suatu unsur yang ada dalam suatu teks, dengan makna yang tetap sama karena sesungguhnya unsur yang hilang tafsirannya tetap berada dalam teks tersebut. Terdapat dua tipe ellipsis yaitu cohesive ellipsis dan incohesive ellipsis. Penelitian ini akan berfokus pada incohesive ellipsis dengan tujuan untuk mengetahui konstruksi pelesapan yang terjadi dalam kalimat berdasarkan praanggapan perspektif antar kalimat (intra-sentence). Penelitian ini akan mendeskripsikan incohesive ellipsis dalam percakapan proses psikoterapi yaitu dalam rekaman audiovisual berjudul Psychoanalytic Psychotherapy with Otto Kernberg, MD. Tujuan penelitian ini adalah mendeskripsikan ellipsis melalui proses pelesapan pada unsur fungsi kalimat dengan menggunakan teori sintaksis dan referensi dari unsur yang mengalami pelesapan menggunakan teori pragmatik. Pengumpulan data dalam penelitian ini menggunakan metode simak dan analisis data menggunakan teksik sisip dan perluasan serta metode padan.
\end{abstract}

Dari jumlah 862 klausa, ditemukan 110 data percakapan dengan proses ellipsis atau pelesapan. Penelitian ini menemukan dua tipe incohesive ellipsis yaitu textual ellipsis dan structural ellipsis. Data paling banyak ditemukan pada textual ellipsis dengan pelesapan pada unsur fungsi kalimat sebanyak 102 data dan, structural ellipsis sebanyak 8 data. Unsur fungsi kalimat yang dilesapkan yaitu subject (S), object (O) dan complement (C) serta gabungan dari beberapa satuan unsur fungsi kalimat membentuk satu rangkaian struktur yaitu S-P, P-S, S-PO, S-P-C, dan S-P-A. Selanjutnya, reference text yang digunakan dalam data penelitian ini yaitu anaphoric ellipsis sebanyak 98 data dan cataphoric ellipsis sebanyak 3 data. Yang paling banyak mengalami pelesapan atau ellipsis adalah tipe textual ellipsis pada unsur fungsi kalimat subject-predicate (S-P) dengan total data 26 (23,6\%) dari 110 data dengan bentuk acuan anaphoric ellipsis.

Kata kunci: ellipsis; syntactic analysis; clause elements; incohesive ellipsis; psychotherapy conversation

\title{
PENDAHULUAN
}

Dalam percakapan yang bersifat informal, penutur cenderung mengabaikan aturan tata bahasa dalam penggunaan bahasa, namun maksud dari percakapan tersebut tetap tersampaikan dengan baik. Hal ini menjelaskan bahwa struktur kalimat (syntax) dan tata bahasa (grammar) tidak diikuti kaidahnya dalam sebuah percakapan. Pada struktur kalimat, terkadang ada satu fungsi dari keseluruhan fungsi kalimat yang hilang atau dilesapkan sehingga menghasilkan kalimat yang tidak lengkap secara gramatikal. Fenomena pelesapan dalam ranah sintaksis disebut syntactic ellipsis.

Elllipsis atau pelesapan adalah hilangnya elemen yang dapat disimpulkan melalui konteks, adanya ketidakcocokan antara bentuk dan makna yang artinya bahwa tidak ada bentuk, tetapi maknanya dapat dipahami. Fenomena pelesapan muncul diasumsikan sebagai strategi penutur untuk menyembunyikan informasi dengan menghilangkan bagian penting dalam percakapan. Tujuan dari ellipsis ini biasanya untuk kepraktisan, menghemat ruang dan menghindari terjadinya repetisi atau pengulangan yang tidak perlu dan cenderung mengganggu. Secara teoritis, unsur yang dilesapkan dapat berupa unsur yang berfungsi sebagai subjek, predikat dan objek. (Alwi, et al 1998). Dalam percakapan, suatu unsur mengalami pelesapan bukan sebagai strategi cohesive atau keterpaduan antar kalimat namun diperlukan pengetahuan lebih dalam mengenai struktur pelesapan sehingga yang akan dipelajari dalam penelitian ini yaitu incohesive ellipsis dan reference atau acuan untuk mengetahui bentuk asal dari pelesapan. Berikut contoh pelesapan dalam percakapan:

Q: Is there a blue wallet?

A: No, there is not a blue wallet 
Dalam contoh diatas, terdapat unsur yang dilesapkan atau mengalami ellipsis. Tipe pelesapan yang terjadi termasuk dalam pelesapan tekstual atau textual ellipsis. Hal ini dikarenakan unsur yang dilesapkan dapat ditafsirkan melalui konteks tertentu. Dalam menafsirkan pelesapan pada percakapan diatas, interpretasi dari pelesapan dapat diketahui dari ujaran dalam pertanyaan yaitu is there a blue wallet, seseorang menanyakan apakah ada dompet yang berwarna biru, lalu lawan bicara menjawab no yang dalam konteks ini berarti tidak adanya dompet berwarna biru, sehingga seharusnya lawan bicara menjawab, tidak ada dompet yang berwarna biru atau no, there is not a blue wallet. Dari struktur kalimat, bagian yang dilesapkan dari jawaban itu adalah fungsi subject, predicate, dan complement (S-P-O). Reference atau acuan dari pelesapan dari percakapan digunakan reference text yang berarti bahwa acuan dapat ditelusuri menggunkan teks yang tersedia dan termasuk dalam anaphoric ellipsis yaitu unsur yang mengalami pelesapan berada pada unsur yang telah muncul sebelumnya yaitu pada pertanyaan.

Dalam penelitian ini, peneliti akan membahas pelesapan dalam percakapan bertema psikoterapi. Psikoterapi sendiri adalah metode yang digunakan untuk merawat kejiwaan, emosi dan gangguan kejiwaan tertentu. Dalam definisinya, dalam The Oxford English Dictionary mengemukakan bahwa psikoterapi adalah pengobatan pada gangguan pikiran atau kepribadian dengan metode psikologis atau psikofisiologis. Percakapan dalam psikoterapi mengandung strategi komunikasi yang dilakukan oleh terapis dalam menggali informasi dari pasien. Maka dari itu respon dari pasien juga bermacammacam, salah satunya dengan menggunakan strategi komunikasi berupa pelesapan atau ellipsis pada percakapan. Untuk mengetahui strategi percakapan, akhirnya penelitian ini dilakukan.

Penelitian sebelumnya mengenai pelesapan sudah sering dilakukan namun masih sangat jarang ellipsis dikaji pada tema percakapan psikoterapi. Berikut penelitian penelitian yang sudah dilakukan namun terdapat perbedaan pada objek kajiannya.

Yang pertama, penelitian dilakukan oleh Azhar pada tahun 2010. Penelitian ini menganalisis tentang pelesapan yang ada pada bahasa SMS digunakan karena keterbatasan karakter penulisan SMS. Yang kedua, penelitian dilakukan oleh Nugraheni pada tahun 2012. Penelitian ini menganalisis dalam hal bentuk pelesapan dan dampak penggunaan pelesapan yang terjadi pada teks terjemahan Al-Quran. Dampak dari pelesapan yang terjadi pada teks terjemahan yang mengandung etika berbahasa ada yang berpengaruh terhadap kejelasan makna dan ada pula yang tidak berpengaruh terhadap kejelasan makna. Pelesapan yang tidak berdampak terhadap kejelasan makna sebanyak 77,4 \%. Sementara itu, pelesapan yang mempengaruhi kejelasan makna sebanyak 22,6\%. Lalu yang terakhir, penelitian dilakukan oleh Mubarokah pada tahun 2015. Penelitian ini meneliti pelesapan unsur kalimat pada surat kabar Solopos, yaitu pelesapan S, P, O, dan K pada rubik surat kabar.

Maka dari itu, rumusan masalah dalam penelitian ini adalah unsur fungsi kalimat apa sajakah yang mengalami ellipsis dan reference atau acuan dari kalimat yang mengalami ellipsis pada percakapan psikoterapi. Kemudian, tujuan dari penelitian ini yaitu mendeskripsikan pelesapan pada unsur fungsi kalimat dalam tipe incohesive ellipsis serta mendeskripsikan reference atau acuan dari kalimat yang mengalami ellipsis pada percakapan psikoterapi. Berikut beberapa teori yang digunakan dalam penelitian ini.

\section{LANDASAN TEORI}

\section{Sintaksis}

Trask (1998: 268) menyebutkan bahwa "Syntax is the branch of linguistics which studies sentence structure". la mengemukakan bahwa sintaktis merupakan cabang dari linguistik yang mempelajari struktur kalimat. Selain itu, menurut O'Grady (1996:181), "Syntax is considered as the system of rules and categories that underlies sentence formation in human language", atau dengan kata lain sintaksis dianggap sebagai suatu sistem dari aturan-aturan dan kategori-kategori yang menggaris bawahi formasi kalimat dalam bahasa manusia. Jadi, sintaksis adalah suatu sistem yang disusun oleh aturan dan kategori yang mempengaruhi bentuk kalimat yang terdapat pada bahasa yang digunakan oleh manusia.

\section{a. Ellipsis}

Pelesapan atau ellipsis merupakan penghilangan suatu unsur yang ada dalam suatu teks, namun tidak menyebabkan makna teks tersebut hilang atau tidak dapat dipahami karena sesungguhnya 
unsur yang hilang tersebut tafsirannya tetap berada dalam teks tersebut. Tujuan dari ellipsis ini biasanya untuk menghemat ruang dan menghindari terjadinya repetisi atau pengulangan yang tidak perlu dan cenderung mengganggu. Teori pelesapan ini dipertegas oleh Trask (1999:88) yaitu "Ellipsis is the omission from a sentence or an utterance of material which is logically necessary but which is recoverable from the context". Sebuah kata atau susunan kata dapat ditiadakan atau dihapus bila pembaca atau pendengar masih tetap dapat mengerti dan memahami suatu kalimat tanpa kata atau susunan kata tersebut.

Dalam pengertian lain, ellipsis atau pelesapan merupakan penghilangan suatu unsur, pelesapan dapat diinterpretasikan sebagai bentuk dari substitusi yang unsurnya tidak digantikan dengan unsur lain. Hal ini sejalan dengan definisi Siahaan (2008:130), "Ellipsis refers to the deletion of the linguistic unit, which is traceable or recoverable from its contexts". Pelesapan mengacu pada peniadaan unit linguistik yang dapat dipulihkan melalui konteks kalimat. Konteks dalam pelesapan menjadi hal penting untuk mengetahui acuan dari hilangnya suatu unsur dalam kalimat.

\section{b. Incohesive Ellipsis}

Incohesive ellipsis adalah pelesapan yang berfokus pada konstruksi pelesapan yang terjadi dalam kalimat atau antar klausa yang merupakan pranggapan berdasarkan perspektif antar kalimat (intra-sentence). Selanjutnya, Quirk \& Greenbaum (1990) mengkategorikan incohesive ellipsis dalam tiga tipe yaitu tekstual ellipsis, structural ellipsis, dan situational ellipsis.

\section{c. Textual Ellipsis}

Textual ellipsis memiliki hubungan yang kuat dengan kohesi yaitu untuk mengidentifikasi unsur yang telah dilesapkan. Menurut Biber, Johansson, Leech, Conrad, \& Finegan (1999), textual ellipsis didefinisikan sebagai unsur telah dikembalikan dari pelesapan pada konteks linguistik. Oleh karena itu, dapat dikatakan bahwa untuk menafsirkan textual ellipsis itu tergantung pada unsur yang telah dikatakan atau ditulis dalam konteks tertentu. Selanjutnya, Quirk \& greenbaum (1990) mengkategorikan textual ellipsis menjadi anaphoric dan cataphoric ellipsis. Dalam pembentukannya, anaphoric yaitu interpretasi dari pelesapan berada pada unsur yang telah muncul sebelumnya. Contoh berikut dapat membantu untuk mengilustrasikan definisi tersebut:

She was poor but she was hones (Swan, 2001)

Sebaliknya, cataphoric adalah interpretasi dari pelesapan berada pada unsur yang muncul setelahnya. Menurut Broughton's (1990), cataphoric ellipsis jarang ditemukan dan kemudian membuat kalimat menjadi sedikit lebih sulit untuk dibaca.

Thore who prefer to stay indoors, can stay indoors (Quirk \& Greenbaum, 1990)

\section{d. Textual ellipsis with focus on the ellipted elements}

Pada bagian ini, kita akan membahas tentang unsur yang hilang yang terjadi pada pelesapan tekstual. Unsur yang dilesapkan merupakan bagian dari sebuah klausa. Dalam English Syntax, $A$ student's grammar book and workbook, Rafajlovičová (2012), unsur klausa atau fungsional klausa adalah subject, predicate, complement, object, attribute and adverbial. Berikut penjelasan mengenai elemen klausa.

\section{e. Clause Elements}

Dalam English Syntax, A student's grammar book and workbook, Rafajlovičová (2012), elemen klausa atau fungsional klausa adalah subject, predicate, complement, object, attribute and adverbial. Berikut penjelasan mengenai elemen klausa.

\section{1) Subjek}

Unsur kalimat yang menunjukkan pelaku disebut subjek. Subjek sebuah kalimat merupakan sesuatu yang dibicarakan dan berada pada awal kalimat. Subjek juga biasanya berupa kata atau kelompok kata yang dibendakan. Sementara itu, Quirk \& Greenbaum (1973:11) menjelaskan, "The subject of the sentences has a close general relation to what is being discussed 
the "theme" of the sentences with the normal implication that something new (the predicate) is being said about "a subject" that has already been introduced in earlier sentences".

Contoh: Lily feeds her cat everyday. (Lily sebagai subjek)

2) Predikat

Predikat merupakan salah satu unsur pokok selain subjek pada suatu kalimat. Predikat ini muncul setelah subjek. Hal ini sejalan dengan pendapat Hornby "Predicate is part of statement which says something about the subject, for example: is sort in life is sort", (Oxford advanced Learner's Dictionary of Current English (Hornby, 1867:656). Dari pernyataan di atas dapat disimpulkan bahwa predikat adalah bagian dari kalimat yang menjelaskan suatu tindakan yang dilakukan oleh subjek.

Contoh: Sherlock eats meatball (eats sebagai predikat)

3) Objek

Objek ini merupakan bagian kalimat yang muncul setelah kata kerja transitif. Jika yang muncul dalam suatu kalimat yaitu kata kerja intransitif, fungsi sintaksis objek ini diganti dengan keterangan (adverb). Richards, et al (1985:6) mengungkapkan bahwa "Object is the noun phrase or pronoun in sentences with transitive verb, which is traditionally described as being affected by action of the verb. The object of a verb can be affected by the verb either directly or indirectly".

Dari paparan di atas, objek dapat berupa kata benda, frase nomina, klausa nomina yang kehadirannya ditentukan oleh verba yang berupa verba transitif.

Contoh: My sister studies Science in the school. (science sebagai objek)

\section{4) Keterangan}

Unsur lain yaitu keterangan. Keterangan merupakan kata yang menjelaskan atau menambahkan arti dari kata kerja, kata sifat, atau kata keterangan lainnya pada suatu kalimat. Pernyataan tersebut dijelaskan oleh Richards, et al. (1985:6) yaitu, "Adverb is a word that describes or adds to the meaning of a verb, an adjective, another adverb or a sentence and which answers such question as how?, where?, or when?".

Contoh: My little brother played basketball in the backyard.

(in the backyard sebagai adverb of place atau keterangan tempat)

\section{f. Structural Ellipsis}

Kristal (2004) mengidentifikasis structural ellipsis sebagai jenis pelesapan yang memerlukan pemahaman tata bahasa untuk menentukan bentuk lengkap dari sebuah kalimat. Sebagai contoh:

I believe that you are mistaken.

Elemen lain yang dapat dilesapkan dalam structural ellipsis adalah determiner, partikel, kata ganti dan lain-lain. Selanjutnya, Quirk \& Greenbaum (1990) mengklaim bahwa structural ellipsis biasanya terjadi dalam blok-language, seperti judul buku dan surat kabar serta berbagai tulisan serupa lainnya. Berdasarkan kemunculannya, dapat dikatakan bahwa structural ellipsis terbentuk sebagai bagian dari proses menghemat bahasa dengan melesapkan informasi yang dianggap kurang penting dalam strukturnya, seperti dalam contoh berikut.

The US heading for a new slump. (Quirk \& Greenbaum, 1990)

Selanjutnya, Quirk \& Greenbaum (1990) menyadari bahwa pelesapan situasional dan struktural kadang cukup sulit dibedakan satu sama lain karena tidak ada garis penentu yang jelas di antara keduanya.

\section{g. Situational Ellipsis (Elisoin)}

Situational ellipsis juga dikenal sebagai elision adalah jenis lain dari elliptical structure (Tárnyiková, 1993). Pelesapan ini mengacu pada bentuk kelalaian yang biasa digunakan dalam pidato informal. 
Berikutnya, pelesapan pada bagian pertama dari kalimat juga sering disebut sebagai initial ellipsis. Biber et al. (1999) lalu mendefinisikan situational (initial) ellipsis sebagai kasus pelesapan kata dengan nilai informasi yang rendah secara konstektual. Situational ellipsis tergantung pada situasi dan bukan pada hubungan tekstual. Oleh karena itu, pelesapan ini tidak dianggap sebagai bagian dari kohesi dalam teks.

Berikut contoh dari elision:

I am glad you think so

It is strange how the ants come in when it's about to rain.

(Huddleston \& Pullum, 2002)

\section{Pragmatik}

Pragmatik adalah ilmu bahasa yang mempelajari pemakaian bahasa yang dikaitkan dengan konteks pemakaiannya. Makna bahasa tersebut dapat dimengerti bila diketahui konteksnya. Batasan pragmatik adalah aturan-aturan pemakaian bahasa mengenai bentuk dan makna yang dikaitkan dengan maksud pembicara, konteks dan keadaan. Wijana (1996:2) menekankan pentingnya konteks dalam pragmatik, beliau menyebutkan bahwa pragmatik mengkaji makna yang terikat konteks.

Pragmatik berkaitan dengan interpretasi suatu ungkapan yang dibuat mengikuti aturan sintaksis tertentu dan cara menginterpretasi ungkapan tersebut di dalam konteks. Definisi tersebut terlihat bahwa pemahaman bahasa merujuk pada fakta bahwa untuk mengerti sesuatu ungkapan bahasa diperlukan juga pengetahuan di luar makna kata dan hubungan tata bahasanya, yaitu hubungan dengan konteksnya. Dalam literatur yang berkaitan dengan pragmatik, ada pula yang menekankan kepada struktur bahasa, aspek makna tertentu dan hakikat ketergantungan dengan konteks.

\section{Referensi}

Menurut Raphael Salkie (1995:64) mengemukakan bahwa kata-kata referensi tidak memiliki makna yang utuh di dalam situasi apapun. Referensi harus memiliki rujukan kata pengiringnya untuk menciptakan makna utuh. Referensi teks melibatkan kata atau kalimat pengiring sebelum atau sesudahnya, hal ini disebut referensi teks (text reference). Ketika referensi merujuk pada dunia nyata disebut referensi situasi (situation reference). Dapat disimpulkan bahwa referensi ialah relasi antara arti atau maksud dari sebuah kata dengan pengiringnya di dalam sebuah teks.

Selanjutnya, Quirk et al. (1985) membagi dua tipe referensi pelesapan, yaitu pelesapan awal (anaphoric) dan pelesapan akhir (cataphoric). Kedua hal tersebut sudah dijelaskan dalam Textual Ellipsis.

\section{a. Psychoanalytic Psychotherapy with Otto Kernberg, MD}

Psychoanalytic Psychotherapy with Otto Kernberg, MD merupakan dokumentasi dari proses psikoterapi yang dilakukan oleh Otto Kernberg. Proses psikoterapi tersebut menggali kejiwaan pasien menggunakan teknik Transference-focused psikoterapi (TFP). Transference-focused psikoterapi (TFP) merupakan pengobatan untuk gangguan kepribadian yang parah, khususnya gangguan kepribadian dan narsisistik. TFP menggabungkan pendekatan psikodinamik dengan struktur dan limit-setting. Tujuan perawatan adalah perubahan kepribadian seperti yang tercermin dalam kehidupan interpersonal dan pekerjaan mereka serta mengurangi gejala-gejala yang menimbulkan hal buruk pada kepribadian.

\section{METODE PENELITIAN}

Sumber data penelitian ini adalah rekaman audiovisual dan skrip percakapan Psychoanalytic Psychotherapy with Otto Kernberg, MD. Data berupa kata, frasa, dan klausa yang mengalami pelesapan pada percakapan. Data penelitian didapatkan dengan teknik simak. Selanjutnya, data tersebut diidentifikasi dan dikelompokan berdasarkan bentuknya. Pada analisis data, peneliti menggunakan teknik sisip dan perluasan pada analisis sintaksis. Menurut Sudaryanto (1993) teknik sisip dilaksanakan dengan menyisipkan "unsur" tertentu di antara unsur-unsur lingual yang ada. Kemudian teknik perluasan dilaksanakan dengan memperluas satuan lingual yang bersangkutan ke 
kanan atau ke kiri, dan perluasan itu menggunakan "unsur" tertentu. Penelitian ini juga menggunakan metode padan pada analisis pragmatik.

\section{HASIL DAN PEMBAHASAN}

Dari jumlah 862 klausa, ditemukan 110 data berupa ellipsis atau pelesapan. Hasil terbanyak ditemukan pada textual ellipsis dengan pelesapan pada unsur fungsi kalimat sebanyak 102 data sedangkan structural ellipsis ditemukan 8 data. Unsur fungsi kalimat yang dilesapkan yaitu subject (S), object $(\mathrm{O})$ dan complement $(\mathrm{C})$ serta gabungan dari beberapa satuan unsur fungsi kalimat membentuk satu rangkaian struktur yaitu S-P, P-S, S-P-O, S-P-C, dan S-P-A. Selanjutnya, reference text yang digunakan dalam data yaitu anaphoric ellipsis sebanyak 98 data dan cataphoric ellipsis sebanyak 3 data pada beberapa unsur fungsi kalimat. Berikut hasil penelitian disajikan pada sebuah tabel.

Tabel 1. Data Ellipsis atau Pelesapan

\begin{tabular}{|c|c|c|c|c|}
\hline NO & Clause Elements & Reference & Textual Ellipsis & Structural Ellipsis \\
\hline \multirow[t]{2}{*}{1} & \multirow[t]{2}{*}{ Subject } & Anaphoric & 3 & \multirow[t]{2}{*}{2} \\
\hline & & Cataphoric & 0 & \\
\hline \multirow[t]{2}{*}{2} & \multirow[t]{2}{*}{ Object } & Anaphoric & 0 & \multirow[t]{2}{*}{0} \\
\hline & & Cataphoric & 2 & \\
\hline \multirow[t]{2}{*}{3} & \multirow[t]{2}{*}{ Complement } & Anaphoric & 6 & \multirow[t]{2}{*}{0} \\
\hline & & Cataphoric & 1 & \\
\hline \multirow[t]{2}{*}{4} & \multirow[t]{2}{*}{ Subject-Predicate } & Anaphoric & 26 & \multirow[t]{2}{*}{0} \\
\hline & & Cataphoric & 0 & \\
\hline \multirow[t]{2}{*}{5} & \multirow[t]{2}{*}{ Predicate-Subject } & Anaphoric & 2 & \multirow[t]{2}{*}{6} \\
\hline & & Cataphoric & 0 & \\
\hline 6 & Subject-Predicate-Object & Anaphoric & 34 & 0 \\
\hline 7 & $\begin{array}{l}\text { Subject-Predicate- } \\
\text { Ccomplement }\end{array}$ & Anaphoric & 24 & 0 \\
\hline \multirow[t]{2}{*}{8} & $\begin{array}{c}\text { Subject-Predicate- } \\
\text { Adverb }\end{array}$ & Anaphoric & 4 & 0 \\
\hline & Total & & 102 & 8 \\
\hline
\end{tabular}

Setelah mengetahui hasil penelitian, selanjutnya adalah analisis data. Peneliti akan mendeskripsikan textual ellipsis yang didalamnya terdapat pelesapan pada unsur fungsi kalimat serta structural ellipsis dan deskripsi dari reference atau acuan dari proses pelesapan. Berikut analisis pada beberapa contoh data.

\section{TEXTUAL ELLIPSIS}

Textual ellipsis adalah pelesapan yang dapat didefinisikan melalui unsur yang dapat dikembalikan dengan konteks dalam komunikasi. Data yang ditemukan dalam pelesapan tekstual sebanyak 89 data dengan reference text atau acuan yang bisa ditelusuri dari kalimat sebelumnya dan bersifat anaphoric dan cataphoric. Berikut pembahasan tentang bentuk pelesapan berdasarkan pada unsur yang dilesapkan.

\section{b. Pelesapan Subject}

Pelesapan subjek merupakan gejala gramatikal yang berupa peniadaan unsur pengisi subjek pada suatu konstruksi bahasa. Seperti terlihat pada contoh berikut ini:

Data 78:

KENGBERG: Well, she could have loved you on the one hand, but then becomes increasingly angry, resentful, and frightened

\begin{tabular}{lllll}
\hline & but then & she & becomes & increasingly angry, resentful, and frightened \\
Fungsi & Conj & S & P & C
\end{tabular}


Dari contoh kalimat dalam data 78, kalimat mengalami pelesapan yaitu textual ellipsis. Konteks pada kalimat diatas adalah Kengberg mengatakan bahwa ada seseorang mencintaimu namun kemudian berubah menjadi marah, benci dan takut (Well, she could have loved you on the one hand, but then becomes increasingly angry, resentful, and frightened). Klausa sebelum konjungsi, yaitu she could have loved you on the one hand merupakan klausa yang secara sintaksis mempunyai fungsi yang lengkap. Sebaliknya klausa sesudah konjungsi but merupakan klausa tak lengkap. Ketidaklengkapan itu disebabkan ada salah satu unsur yang berfungsi sebagai subjek dilesapkan. Secara kontekstual, unsur yang dilesapkan itu mengacu secara anaforis pada subjek klausa sebelumnya, yaitu she.

\section{c. Pelesapan Object}

Pelesapan objek merupakan tidak adanya suatu unsur pengisi objek pada pada suatu konstruksi klausa. Seperti pada data 69, sebagai berikut:

\section{Data 69:}

ALFRED: I don't have friends in the sense of people who I can trust all the time. I have colleagues.

I have, my sister is very close to me. I'm very close to my sister.

\begin{tabular}{llll} 
& $\mathrm{I}$ & have & my sister \\
Fungsi & $\mathrm{S}$ & $\mathrm{P}$ & $\mathrm{O}$ \\
\hline
\end{tabular}

Data 69 merupakan kalimat yang mengandung predikat transitif dimana predikatnya tersebut memerlukan objek untuk dikenai aksi. Namun, objek pada klausa tersebut dilesapkan karena penutur mengubah kalimatnya dari I have my sister menjadi my sister is very close to me. Secara kontekstual, penutur dan mitra tutur mengetahui bahwa bahwa penutur mengalami slip tongue sehingga membuat kalimat yang dibuatnya beruntun. Hal yang dimaksudkan oleh penutur adalah selain dia memiliki mitra kerja (collagues), dia juga akan mengatakan bahwa dia memiliki saudara perempuan (sister) namun dia mengubah kalimatnya menjadi kalimat yang menceritakan kedekatan penutur dan saudaranya tersebut (my sister is very close to me). Unsur yang dilesapkan itu mengacu secara cataforis pada objek klausa yang berada pada kalimat sesudahnya, yaitu my sister.

\section{d. Pelesapan Complement}

Pelesapan complement atau pelengkap yaitu tidak hadirnya unsur pelengkap pada suatu kalimat. Hal ini terlihat pada contoh berikut:

\section{Data 11:}

KERNBERG: Was it a satisfactory relationship as far as you were concerned?

ALFRED: For me it was, but for her, it wasn't.

\begin{tabular}{lllll} 
& For me & It & was & a satisfactory relationship \\
Fungsi & A & S & P & C \\
\hline
\end{tabular}

Pada contoh data 11, percakapan terjadi antara Kernberg dan Alfred dan Alfred menjawab pertanyaan dari Kernberg dengan konstruksi unsur kalimat yang tidak lengkap namun unsur kalimat tersebut dapat dikembalikan dengan konteks percakapan. Saat penutur mendapat pertanyaan, apakah hubungan kalian merupakan hubungan yang menyenangkan (was it a satisfactory relationship), penutur menjawab iya bagiku namun bagi dia tidak for me it was, but for her, it wasn't. Maksud dari jawaban penutur adalah, bagi dirinya mungkin itu adalah hubungan yang menyenangkan namun menurut dia (pasangannya) hubungan itu tidak menyenangkan. Seharusnya kalimat yang muncul adalah for me it was a satisfactory relationship, but for her, it wasn't a satisfactory relationship. Unsur yang dilesapkan pada percakapan ini adalah unsur pelengkap atau complement. Reference yang digunakan dalam percakapan tersebut yaitu anaphoric karena kalimat yang mengalami pelesapan membutuhkan pelengkap yaitu $a$ satisfactory relationship yang berada pada kalimat pertanyaan.

\section{e. Pelesapan Subject dan Predicate}

Pelesapan subjek dan predikat merupakan gejala gramatikal yang berupa peniadaan unsur pengisi subjek dan predikat pada suatu konstruksi sebuah klausa. 
Data 5:

KERNBERG: And the girlfriend that left you, what's her name?

ALFRED: Saskia.

\begin{tabular}{llll} 
& Hername & Is & Saskia \\
Fungsi & $\mathrm{S}$ & $\mathrm{P}$ & $\mathrm{C}$ \\
\hline
\end{tabular}

Pelesapan yang terjadi pada contoh data 5 yaitu unsur pengisi subjek dan predikat. Hal ini dikarenakan pada data 5, klausa berupa jawaban dari pertanyaan dan jawaban tersebut hanya mengisi fungsi objek yaitu Saskia sehingga struktur klausa tidak menghadirkan fungsi subjek dan predikat. Unsur pengisi subjek dan predikat merujuk secara anaforis pada pertanyaan dari percakapan yaitu what is her name dengan konstruksi terbalik menjadi her name is. Selanjutnya, reference yang terjadi dalam contoh data ini adalah reference text yang mana acuan dari pelesapan terdapat dalam kalimat yang terkandung dalam percakapan bukan menarik acuan lain dari situasi (reference situation).

\section{f. Pelesapan Predicate dan Subject}

Unsur pengisi predikat dan subjek secara beruntun dilesapkan pada suatu konstruksi bahasa berupa kalimat pertanyaan (interrogative). Berikut contoh pada data 6 :

Data 6:

KERNBERG: And the girlfriend that left you, what's her name?

ALFRED: Saskia.

KERNBERG: Saskia?

\begin{tabular}{llll} 
& Is & hername & Saskia? \\
Fungsi & $\mathrm{P}$ & $\mathrm{S}$ & $\mathrm{O}$ \\
\hline
\end{tabular}

Contoh dari data 6 yaitu pelesapan pada unsur fungsi predikat dan subjek yang terjadi secara beruntun yaitu fungsi predikat lalu subjek. Dalam percakapan, pelesapan terjadi karena penutur melakukan kepraktisan pada pertanyaan dari asal konstruksi kalimat is her name Saskia? menjadi Saskia? yang merupakan klarifikasi dari jawaban mitra tutur. Reference yang terjadi dalam percakapan yaitu anaphoric karena unsur yang dilesapkan mengacu pada kalimat sebelumnya yaitu pertanyaan dari penutur kepada mitra tutur.

\section{g. Pelesapan Subject, Predicate dan Object}

Pelesapan subjek, predikat dan objek merupakan peniadaan unsur pengisi subjek, predikat dan objek pada suatu konstruksi klausa. Berikut contoh pelesapan pada data 8:

Data 8:

KERNBERG: how long had you been living with her?

ALFRED: For four years.

\begin{tabular}{lllll}
\hline & I & had been living & with her & for four years \\
Fungsi & $\mathrm{S}$ & $\mathrm{P}$ & $\mathrm{O}$ & $\mathrm{C}$ \\
\hline
\end{tabular}

Dari data 8, tidak semua fungsi klausa hadir secara lengkap. Klausa pada data 8 hanya mencakup unsur fungsi keterangan atau Adverb. Pelesapan yang terjadi yaitu konstruksi unsur subjek, predikat dan objek mengacu secara anaforis pada pertanyaan oleh mitra tutur. Saat menjawab pertanyaan, penutur seharusnya menjawab dengan kostruksi kalimat ynag lengkap agar menghindari ambiguitas. Klausa yang dilesapkan yaitu I had been living with her sehingga konstruksi yang benar menjadi I had been living with her for four years.

\section{h. Pelesapan Subject, Predicate dan Complement}

Pelesapan juga terjadi pada konstruksi subjek, predikat, dan pelengkap seperti pada data 9:

Data 9:

KERNBERG: So I found something confusing there. Are you surprised by what I'm saying?

ALFRED: Not entirely. But I realized that I, for a moment that I think I can trust you.

\begin{tabular}{llllll}
\hline & I & am & not entirely & suprised & by what you're saying \\
Fungsi & $\mathrm{S}$ & $\mathrm{P}$ & $\mathrm{A}$ & $\mathrm{P}$ & $\mathrm{C}$ \\
\hline
\end{tabular}


Pada data 9, terdapat konstruksi kalimat yang hanya memenuhi satu unsur yaitu adverb atau keterangan. Melihat dari konstruksi pada pertanyaan, unsur yang dilesapkan pada kalimat jawaban adalah subjek, predikat, dan pelengkap. Pertanyaan dalam percakapan tersebut yaitu are you surprised by what I'm saying? dan dijawab dengan not entirely. Reference dari unsur yang mengalami pelesapan dapat dicari dan mengacu pada kalimat sebelumnya (anaphoric) yaitu dalam pertanyaan are you surprised by what I'm saying? sehingga bentuk konstruksi lengkap dari jawaban penutur adalah I am not entirely surprised by what you're saying.

\section{i. Pelesapan Subject, Predicate dan Adverb}

Pelesapan subjek, predikat dan keterangan juga terjadi pada percakapan. Berikut terdapat pada contoh 24.

Data 24:
KERNBERG: ... she was thinking under conditions when she was not thinking that. Am I hearing
correctly?
\begin{tabular}{rlll} 
ALFRED: Yes, yes. \\
Yes, yes. & You & are hearing & correctly \\
Fungsi & $\mathrm{S}$ & $\mathrm{P}$ & $\mathrm{A}$ \\
\hline
\end{tabular}

Pelesapan terjadi pada unsur fungsi subjek, predikat dan keterangan. Hal ini merujuk pada pertanyaan yang diajukan penutur lain (anaphoric). Pada percakapan tersebut, penutur hanya menjawab singkat yaitu yes, yes dari pertanyaan panjang mitra tuturnya. Namun, jawaban singkat tersebut sejatinya sudah mengalami pelesapan pada konstruksi kalimat lengkap. Seharusnya, penutur dapat menjawab dengan konstruksi kalimat yang lengkap yaitu yes, yes you are hearing correctly.

\section{STRUCTURAL ELLIPSIS}

Jenis pelesapan yang memerlukan pemahaman tata bahasa untuk menentukan bentuk lengkap dari sebuah kalimat disebut sebagai structural ellipsis. Data yang ditemukan dalam pelesapan struktural sebanyak 21 data dengan tidak disertai reference atau acuannya. Berikut pembahasan tentang bentuk pelesapan berdasarkan pada unsur yang diduga dilesapkan dalam struktur kalimat yaitu pelesapan pada subject (S) dan predicate-subject (P-S).

\section{a. Pelesapan Subject}

Pelesapan subjek pada structural ellipsis adalah lesapnya unsur subjek dalam kalimat yang dalam pemahamannya memerlukan pengetahuan tata bahasa, berikut contoh dalam data 110:

Data 110:

ALFRED: You're the therapist, tell me please. What should I say to make you happy?

\begin{tabular}{llll}
\hline & You & tell & me \\
fungsi & $\mathrm{S}$ & $\mathrm{P}$ & $\mathrm{O}$ \\
\hline
\end{tabular}

Pada data 110, ditemukan proses pelesapan atau ellipsis secara struktural pada unsur subjek. Dalam grammar bahasa Inggris (English grammar), kalimat tell me pada kalimat data 110 merupakan kalimat imperative atau kalimat perintah. Verb atau kata kerja dalam kalimat imperative tidak memerlukan adanya penambahan subjek karena subjek you sudah tersirat didalamnya atau disebut dengan elliptical construction. Maka, jika kalimat perintah tersebut dijadikan bentuk kalimat yang lengkap secara structural, kalimattnya menjadi you tell me.

\section{b. Pelesapan Predicate dan Subject}

Pelesapan predikat dan subjek dipahami dengan konstruksi tata bahasa pada bahasa Inggris yang merupakan kalimat pertanyaan atau interrogative sentence. Berikut contoh pelesapan yang terjadi pada predikat dan subjek.

Data 79:

KERNBERG: So I would be biased against you also, really. Right?

\begin{tabular}{llll} 
& Is & It & right? \\
Fungsi & $\mathrm{P}$ & $\mathrm{S}$ & $\mathrm{C}$ \\
\hline
\end{tabular}


Kalimat pada data 79 mengalami pelesapan pada kalimat pertanyaan atau interrogative sentence. Dalam English grammar, kalimat pertanyaan mempunyai konstruksi yaitu kalimat diawali oleh kata kerja (verb) atau kata kerja bantu (auxiliary) dan diikuti oleh subyek. Namun, dalam kalimat pada data 79, unsur yang mengalami pelesapan yaitu pada unsur predikat dan subjek. Secara konteks, pelesapan terjadi karena penutur melakukan kepraktisan kalimat yaitu pada pertanyaan is it right? menjadi right?. Unsur fungsi predikat dan subjek yang dilesapkan tidak merujuk pada kalimat sebelum atau setelahnya namun unsur tersebut ditemukan dalam konteks percakapan.

\section{SIMPULAN}

Berdasarkan analisis data di atas dapat disimpulkan beberapa hal berikut ini.

1. Dari jumlah 862 klausa, ditemukan 110 data kalimat yang mengalami ellipsis atau pelesapan.

2. Dalam percakapan psikoterapi, ditemukan dua tipe incohesive ellipsis yaitu textual ellipsis dan structural ellipsis.

3. Data paling banyak ditemukan pada textual ellipsis dengan pelesapan pada unsur fungsi kalimat sebanyak 102 data dan, structural ellipsis sebanyak 8 data.

4. Unsur fungsi kalimat yang dilesapkan yaitu subject (S), object (O) dan complement (C) serta gabungan dari beberapa satuan unsur fungsi kalimat membentuk satu rangkaian struktur yaitu S-P, P-S, S-P-O, S-P-C, dan S-P-A.

5. Reference text yang digunakan dalam data penelitian ini yaitu anaphoric ellipsis sebanyak 98 data dan cataphoric ellipsis sebanyak 3 data.

6. Bagian yang paling banyak mengalami pelesapan atau ellipsis adalah tipe textual ellipsis pada unsur fungsi kalimat subject-predicate (S-P) dengan total data $26(23,6 \%)$ dari 110 data dengan bentuk reference adalah anaphoric.

\section{DAFTAR PUSTAKA}

Azhar, Iqbal Nurul. 2010. "Style Bahasa SMS". Metalingua Volume 8 Nomer 2 Desember 2010. Trunojoyo: Universitas Negeri Trunojoyo.

Baryadi, Praptomo. 2002. Dasar-dasar Analisis Wacana dalam Ilmu Bahasa. Yogyakarta: Pustaka Gondho Suli.

Carnie, Andrew. 2007. Syntax: A Generative Introduction. Cet. Kedua. Oxford: Blackwell

Halliday, M.A.K and Hassan Ruqaiya. 1976. Cohesion in English. London: Longman Inc.

Hartono, Bambang. 2012. Dasar-Dasar Kajian Wacana. Semarang: Pustaka Zaman.

Kiss, T. \& Alexiadou, A. 2015. Syntax - Theory and Analysis. Germany: Mouton De Gruyter.

Kridalaksana, Harimurti. 2011. Kamus Linguistik Edisi Keempat. Jakarta: Gramedia Pustaka Utama.

Mubarokah, Yulfi Nugraheni. 2015. "Pelesapan Unsur Kalimat Majemuk Pada Rubrik Pendidikan Dan Humoniora Surat Kabar Solopos". Surakarta: Universitas Muhammadiyah Surakarta.

Nugraheni, Dwi. 2012. "Transformasi Pelesapan Pada Teks Terjemahan Al-quran Yang Mengandung Etika Berbahasa". Surakarta: Universitas Muhammadiyah Surakarta.

Moleong, Lexy J. 2001. Metodologi Penelitian Kualitatif. Bandung: Remaja Rosdakarya.

Mulyana. 2005. Kajian Wacana: Teori, Metode, dan Aplikasi Prinsip-Prinsip Analisis Wacana. Yogyakarta: Tiara Wacana.

Paltridge, Brian. 2000. Making Sense of Discourse Analysis. Queensland. Gold Coast

Quirk, Randolph, et al. 1985. A Comprehensive Grammar of the English Language. London: Longman.

Rustono. 1999. Pokok-Pokok Pragmatik. Semarang: IKIP Semarang Press

Schegloff, E. A., Jefferson, G., and Sacks, H. 1977. The Preference for Selfcorrection in the Organization of Repair in Conversation' Language, 53, (361-82).

Soeparno. 2002. Dasar-dasar Linguistik Umum. Yogyakarta: PT. Tiara Wacana Yogya. 
Sudaryanto. 1993. Metode dan Teknik Analisis Bahasa. Pengantar Penelitian Wahana Kebudayaan Secara Linguistik.

Trask, R.L. 1998. Language: The Basics, 2nd edn. London: Routledge.

White, Jonathan. 2013. Language economy in computer-mediated communication: Learner autonomy in a community of practice. In B. Zou, M. Xing, C. Xiang, Y. 